\title{
Marcella O'Grady Boveri (1865-1950) and the chromosome theory of cancer
}

\author{
VICTOR A McKUSICK \\ From the Department of Medicine, Johns Hopkins University School of Medicine, Johns Hopkins Hospital, \\ Baltimore, Maryland 21205, USA.
}

SUMmary Born into a Boston Irish family, Marcella Imelda O'Grady was the first woman graduate in biology from MIT (1885) where she came under the influence of two recent $\mathrm{PhD}$ graduates of Johns Hopkins University, William Townsend Sedgwick and Edmund Beecher Wilson. She taught science at Bryn Mawr School for girls in Baltimore 1885 to 1887 and was teaching assistant with E B Wilson at Bryn Mawr College for women in Bryn Mawr, Pennsylvania, 1887 to 1889 . From 1889 to 1896 she headed the Department of Biology at Vassar College for women in Poughkeepsie, New York. On the recommendation of E B Wilson (who from the first edition in 1896 dedicated his famous book The cell in development and inheritance to Boveri) Marcella went to Würzburg to spend a sabbatical with Boveri. One year later she married Boveri and during the next 18 years until Boveri's untimely death in 1915 she was her husband's close scientific collaborator, especially in his work at the marine zoological stations in Naples and Villefranche, France. She also acquired (from Freiburg) the doctorate she had unsuccessfully attempted to get at Johns Hopkins. Marcella returned to the United States in 1926 and headed the Biology Department at Albertus Magnus College in New Haven. She was there in 1929 when her English translation of her husband's 1914 monograph advancing the chromosome theory of cancer was published. The translation did much to bring that theory to the attention of a wider audience which has thereby been able to rediscover Boveri, despite lack of a reading knowledge of German. Boveri's theory was based on the views that (1) cancer is a cellular problem, (2) cancers originate from a single cell, (3) this cell has an abnormality of its chromosomal constitution, and (4) the chromosomal abnormality which is passed on to all the descendants of the cell of origin is the cause of rapid cell proliferation.

This paper is submitted out of profound respect for Sir Cyril and Lady Clarke who, like Boveri and his wife, have worked closely for many years on problems of biology and medicine.

Recent discoveries by high resolution cytogenetics and new information concerning oncogenes have validated the chromosome theory of cancer advanced by Theodor Boveri (1862-1915) in a monograph published the year before his death. ${ }^{1}$ Professor of Zoology at Würzburg, Boveri was a leading cytologist who, with Sutton, ${ }^{2}$ is also credited for marshalling evidence for the chromosomal basis of mendelism. Here I shall review the role of Boveri's wife and widow in the work that underlay the cancer theory and her role in making the theory widely known through the English translation of his monograph. ${ }^{3}$

Received for publication 10 June 1985 . Accepted for publication 17 June 1985.

\section{Marcella O'Grady}

Marcella Imelda O'Grady was born in Boston on 7 October 1863 and attended Boston Girls' High School. Although she pursued the so-called General Studies IX curriculum, she can be said to have been the first woman to earn the bachelor's degree in biology from Massachusetts Institutè of Technology (SB degree, 1885). ${ }^{4}$

(Several women had been awarded degrees before her-the earliest was Ellen Swallow Richards in 1873-but none of them graduated in biology.) MIT was then quite a different institution from the one we know today. Located in the centre of Boston, it had fewer than 450 students.

Marcella's thesis was entitled 'The sympathetic nervous system of Columbia livia'. At MIT she came under the influence of William Townsend Sedgwick (1855-1921), who had come as Professor of Biology 
at the beginning of Marcella's junior year. ${ }^{5}$ There, furthermore, she first made the acquaintance of Edmund Beecher Wilson (1856-1939) who was to be important in her subsequent career.

Wilson $^{6}$ and Sedgwick ${ }^{5}$ had been classmates at the Sheffield Scientific School of Yale University. Both applied for coveted fellowships to do graduate work at Johns Hopkins University with Newell Martin and William Keith Brooks, ${ }^{7}$ and both were accepted for appointment in 1879 , merely three years after the founding of Johns Hopkins. Daniel Coit Gilman's axiom "Men, not buildings" extended to the support of graduate students as well as faculty. ${ }^{8}$ Not only was Johns Hopkins the first graduate university in America but it was also an elitist institution, where able though impecunious young men could get training. For example, Woodrow Wilson, son of a Presbyterian minister, received his $\mathrm{PhD}$ from Johns Hopkins in 1886 (further mention of this Wilson later).

Sedgwick and E B Wilson completed their PhDs in 1881. Sedgwick remained at Johns Hopkins as Associate in Biology until going to MIT in 1883 . He welcomed E B Wilson (who had been at Williams College in 1883 to 1884 ) as a volunteer member of the MIT faculty during the year that Wilson was waiting to take up his appointment at Bryn Mawr College in Bryn Mawr, Pennsylvania, when it opened in 1885. Together they wrote Textbook of general biology, first published in 1886, which was highly successful through many editions. The book of Huxley and Martin had previously dominated the field. Sedgwick's distinguished career in bacteriology, sanitation, and public health within the framework of MIT and the now long defunct joint Harvard School of Public Health/MIT programme is recounted elsewhere. ${ }^{5}$

But back to Marcella. In a sketchy $\mathrm{CV}$ in her own beautiful handwriting, ${ }^{9}$ under Teaching, she stated that she was in "charge of Science teaching at opening of Bryn Mawr School, Baltimore, 18851887 " (and in the section on Education she referred to a "course in Bryology" she took at Harvard University in the same period). M Carey Thomas, the first Dean and the second President of Bryn Mawr College, Pennsylvania, was the prime mover in the simultaneous founding of the namesake private secondary school for girls in Baltimore. ${ }^{10}$ She was assisted in the founding of the School and College (both of which this year celebrate their centennial) by her friend Mary Elizabeth Garrett who later was to provide critical funds that permitted the opening of the Johns Hopkins Medical School in 1893 on terms stipulated by Miss Garrett, including that women would be admitted on equal terms with men.
Reportedly, Daniel Coit Gilman, first president of Johns Hopkins University, "had discouraged the founding ladies [of Bryn Mawr School] from attempting such high standards . . . he disapproved trying $\underset{\sim}{\stackrel{9}{\sigma}}$ to model the school on schools for boys. He doubted $\bar{O}$ women's ability to profit by the education offered". ${ }^{10}$ At the beginning, there was a physical $\frac{\bar{c}}{7}$ relationship between Bryn Mawr School and JHU; $\stackrel{\mathbb{D}}{\square}$ the School was housed in a rented building on Eutaw Street adjoining the 'campus' of Johns Hopkins University in downtown Baltimore.

After Baltimore, Marcella spent two years, 1887 to 1889 , at Bryn Mawr College in Bryn Mawr, Pennsylvannia, as a teaching fellow in biology with E B Wilson. Founded in 1885 by Quakers, the college included in its faculty another Wilson, who organised the history department and headed it for three years before leaving for professorships at Wesleyan University and Princeton University and, in due course, the Presidency of the United States. E B Wilson headed biology for the first six years. ${ }^{6}$ He was succeeded by Thomas Hunt Morgan (18661945), PhD Johns Hopkins 1890 , who spent 13 years at Bryn Mawr before following Wilson to Columbia University where he spent the most productive part of his career. ${ }^{11}$ (Jacques Loeb ${ }^{12}$ was brought to Bryn Mawr in biology, his first position in America, bu甲 was there for a mere two months, November 1891 to January 1892.)

In 1889 Marcella went to Vassar College (founde बै in 1861) in Poughkeepsie, New York, as head of the Department of Biology which she strengthened greatly during her seven years' tenure. Imbued by the scientific spirit she had acquired from Sedgwick and Wilson, she carried to Vassar College the New Biology of the day. In the summers of 1889,1890 , and 1892 she worked at the Marine Biological Laboratory in Woods Hole, Massachusetts, under Professor C O Whitman, director of the laboratory. (E B Wilson was later director of MBL.) In connection with the centennial of Vassar College, Edna Carter, former Professor of Physics at Vassar and a student of Marcella in the 1890s, wrote: "We were fascinated by Miss O'Grady herself as well as by what she had to give. She had a warm interest in people and an inborn desire to be of service. Many students were helped in the solution of their personal problems. She was young and yet mature, a full professor at twenty-five, making enduring friendships among her students as well as in the faculty. She worked hard giving laboratory practice along with the class work. Biology in those days was open to juniors and seniors, but in her six years at the college, the department grew from one to four members and advanced courses were added". ${ }^{13}$

Marcella's mentor, E B Wilson, became Professor 
of Zoology at Columbia University in 1891 . His first year on the Columbia faculty was spent in Europe, in Munich and at the International Zoological Station in Naples, working mainly with Boveri. Only six years his junior, Wilson was influenced by Boveri (who was then still in Munich) to focus on cytology, which consumed his scientific attention for the rest of his career. Wilson's The cell in development and inheritance (first edition, 1896) was dedicated "To my friend Theodor Boveri". ${ }^{14}$. Wilson stated that
Boveri was "far more than a brilliant scientific discoverer and teacher. He was a many-sided man, gifted in many directions, an excellent painter, and we found many points of contact far outside the realm of science. . . . The best that he gave me was at the Café Heck where we used to dine together, drinking wonderful Bavarian beer, playing billiards, and talking endlessly about all manner of things".

When Marcella O'Grady was looking for an optimal place to spend a sabbatical year, Wilson
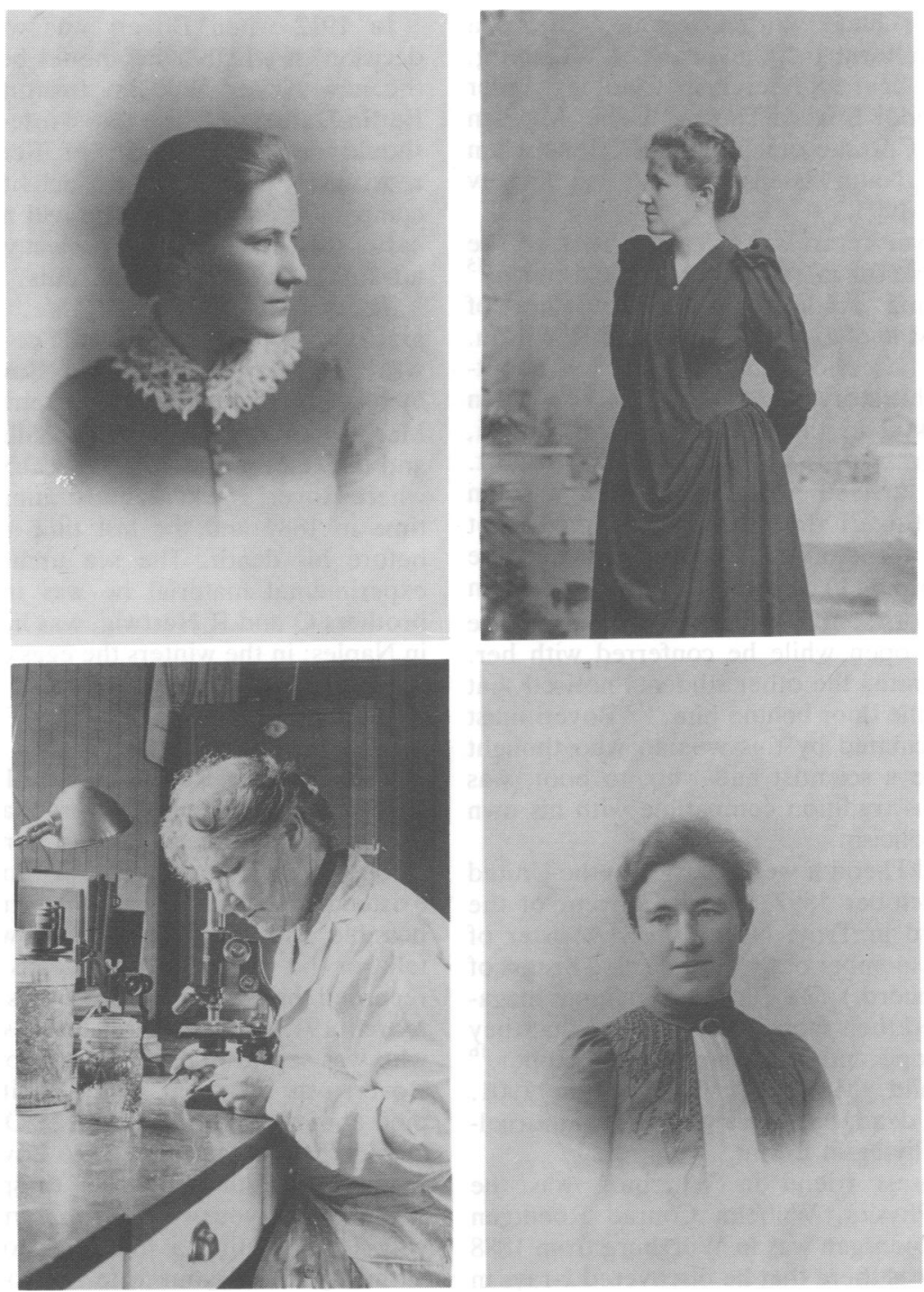

FIG 1 Portraits of Marcella O'Grady Boveri. (Courtesy of Archives of Albertus Magnus College.) Clockwise from top left: in Boston, about 1885; in Poughkeepsie, NY, about 1893; in Baden, Switzerland, about 1900; in New Haven, about 1930 
naturally recommended that she work with Boveri, now in Würzburg. She was the first woman to be admitted to a science department of Würzburg University. (It is likely that Marcella aspired to advanced study in biology at Johns Hopkins, but at the time women were not admitted. Florence Bascom, who for 33 years was head of the Department of Geology at Bryn Mawr College, received the $\mathrm{PhD}$ degree from Johns Hopkins in 1893 but was never listed in class rolls as an official matriculant. It is said that women during that period were permitted to attend lectures only if they sat behind a screen.) In her hand written resumé, ${ }^{9}$ Marcella indicated the following: "University of Würzburg, Germany, one year. Research in Cytology under Professor Theodor Boveri. Thesis: "Ueber Mitosen bei einseitiger Chromosomenbindung", Jenaischen Zeitschrift für Naturwissenschaft. Verlag Gustav Fischer, Jena, 1903".

Marcella never returned to Vassar because she married her professor in 1897. Richard Goldschmidt ${ }^{15}$ has a charming account of the courtship of Theodor and Marcella, told to him by E B Wilson. "One day an American girl applied for admittance to the laboratory. Up to that time no woman had ever worked in the laboratory, and Boveri, a very shy man, was greatly upset by the prospect. Miss O'Grady arrived and was assigned a room to herself as Boveri thought that she might not like to share a room with men. Every day the professor, according to custom, came to check up on the students' work, and he was very careful to leave the door wide open while he conferred with her. After some months the other students noticed that Boveri closed the door behind him."15 Boveri must have been fascinated by this woman who thought and talked like a scientist and who, to boot, was from a religious tradition compatible with his own Bavarian Catholicism.

Marcella and Theodor were married in the United States on 5 October 1897, at the Convent of the Good Shepherd in Troy, New York. (A sister of Marcella was a member of the order called Sisters of the Good Shepherd.) The Tech, MIT alumni magazine, announced their marriage and stated that they sailed for Europe and Würzburg on 7 October. ${ }^{16}$ Their only child, Margreta, was born in 1901. Margreta, now dead, became a well known journalist and writer, living in Berlin.

Boveri's closest friend in Würzburg was the Professor of Physics, Wilhelm Conrad Roentgen (1845-1923). Roentgen was in Würzburg from 1888 to 1900 and it was there that he discovered $x$-rays in 1895. The Boveri-Roentgen friendship was delightfully recounted by Margreta Boveri, ${ }^{17}$ who reproduced many letters from Roentgen to Boveri.
According to Margreta, Roentgen approved strongly of women in science; at least he approved of a scientific education for women. When Marcella arrived in Würzburg, he too was fascinated by the 'zoological Miss', as she was called, and "she was invited by the Röntgens for afternoon coffee every day while she studied there. Röntgen enjoyed her interest in natural sciences very much and also her sheer exuberance. Even during the first year of their acquaintance she was invited to accompany the Röntgens on their vacation trips to Cadenabbia and Baden-Baden".

In 1912 when Boveri was wrestling with the decision of whether he should become director of the new Kaiser Wilhelm Institute for Biology in Berlin-Dahlem, Roentgen wrote to him: "If you should decide in favour of Berlin and have to reorganise your scientific activities, you have a companion and helper who will make things much easier for you and in this respect you would have an advantage over other applicants". ${ }^{17}$

To the end of Boveri's life, Marcella was his gracious hostess and scientific co-worker. Marcella was particularly involved in Boveri's research in cytology and experimental embryology at the Marine Zoological Station at Villefranche, France, and the International Zoological Station at Naples, where Boveri worked almost annually, for the first time in 1887 and the last time in 1914, the year before his death. The sea urchin egg, to which experimental material he was introduced by the brothers $\mathrm{O}$ and $\mathrm{R}$ Hertwig, was his focus of interest in Naples; in the winters the eggs of the roundworm Ascaris megalocephala, available locally, occupied his attention for many years in Munich and Würzburg.

In a letter to Roentgen in 1910, Boveri wrote: "We agree completely on very many things and, in the nearly 17 years of our contact, have lived through much together. We both love a quiet existence, in beautiful natural surroundings if at all possible, with a few close friends with whom we can talk or be silent as one needs to". ${ }^{18}$ Glasser ${ }^{19}$ recorded that Roentgen "spent his 70th birthday (27 March 1915) quietly with his best friend, Boveri, who was seriously ill, in Oberstdorf, Bavaria . . .". Boveri was a patient in the sanitorium there and died about six months later (15 October 1915). On 20 March Roentgen ${ }^{17}$ wrote to Boveri as follows: "It seems to me that my plan to spend the twentyseventh with you will now materialize, and that is why I am writing a few lines to you. I ask you earnestly to tell your wife not to make any-how shall I express myself-special preparations. The times are not conducive to celebrations and I am not in the mood for them, and shall derive the greatest 
pleasure from the fact that our two families are together". After Boveri's death, Roentgen ${ }^{20}$ edited a book of collected remembrances of the great cytologist and had a bust made of him. ${ }^{17}$

After her husband's death in 1915, Marcella remained in Germany until 1926 . They were difficult years because of the post-war circumstances. Roentgen's wife died in 1919. His loneliness was partially relieved by his friendship with Mrs Boveri and her daughter. He regularly spent the Christmas holidays with them in Würzburg. Many of his other friends were now dead or lived abroad. After his death on 10 February 1923, Marcella was executrix for Roentgen's estate. In accordance with his last will, Roentgen's scientific and personal papers and his correspondence, with but few exceptions, were burned. ${ }^{21}$

In the biographical sketch quoted earlier, Edna Carter, Professor of Physics Emeritus at Vassar, wrote: "The aftermath of the war was a very difficult time with the changed attitudes, the depression and the run-away inflation. In $1926 \mathrm{Mrs}$ Boveri was quite ill but she resolved to pay a last visit to America. She had a sister and many friends here and she recovered in the friendly atmosphere so that before the end of the summer she was asked to start a department of biology at . . . Albertus Magnus College [founded in 1925] . . During these years of teaching, Mrs Boveri attended the colloquia at Yale in her field. With her knowledge of foreign scientists and their work, she became a valuable member and made many friends among the Yale professors. In this time, too, many a foreign professor had her to thank for the opportunity to lecture in this country". ${ }^{13}$ Marcella may have had something to do with the visit of Hans Spemann (more about him later) to New Haven to give the Silliman Lectures in 1933. ${ }^{22}$ Goldschmidt wrote that she "spent the rest of her long life as Professor of Zoology at Albertus Magnus College in New Haven, worshipped by the girl students and honored by her many friends. It was an unforgettable pleasure to be her guest in the cozy apartment on the campus and to talk about old times and about science while admiring her perfect poise and nobility of bearing and mind". ${ }^{15}$ Marcella was at Albertus Magnus College in 1929 when her translation of The origin of malignant tumors was published by the Williams and Wilkins Company in Baltimore. ${ }^{3}$

"Shortly after retiring, about 1942 [actually 1943], Marcella became the victim of a progressive disease, but her mind remained clear and she had loving devoted care to the end of her life."13 For a time in her last years she was cared for at the Convent of the Good Shepherd, Wicatunk, New Jersey, where her sister, Mother Mary Immaculata, who died before her, had been. Marcella died on 24 October 1950 in St Francis Hospital in Trenton, New Jersey, and was buried in the cemetery of the Sisters of the Good Shepherd in Wicatunk.

\section{Theodor Boveri $(1862-1915)^{1823-26}$}

Boveri was the second of four sons of a physician in Bamberg, Bavaria. He studied anatomy in Munich under Carl von Kupfer. His PhD thesis (1885) was on the structure of nerve fibres in vertebrates, a subject to which he did not later return. Soon after Boveri completed his doctorate, he transferred to the Zoological Institute in Munich. The new director of the Institute, Richard Hertwig, encouraged him to go into cytological research. Following Hertwig's example he combined morphological and experimental approaches almost from the beginning of his postdoctoral career. He was privat-dozent in Munich University in 1893 when, not yet 31 years old, he was called to Würzburg as Professor of Zoology. There he remained for the rest of his career, declining invitations to succeed Weismann at Freiburg and to organise and direct the new Kaiser Wilhelm Institute in Berlin. He enjoyed many honours including the highest office (Rector Magnificus) in his university and foreign associateship in the National Academy of Sciences of the USA. His untimely death at the age of 53 was said to have been due to tuberculosis; the symptoms, particularly

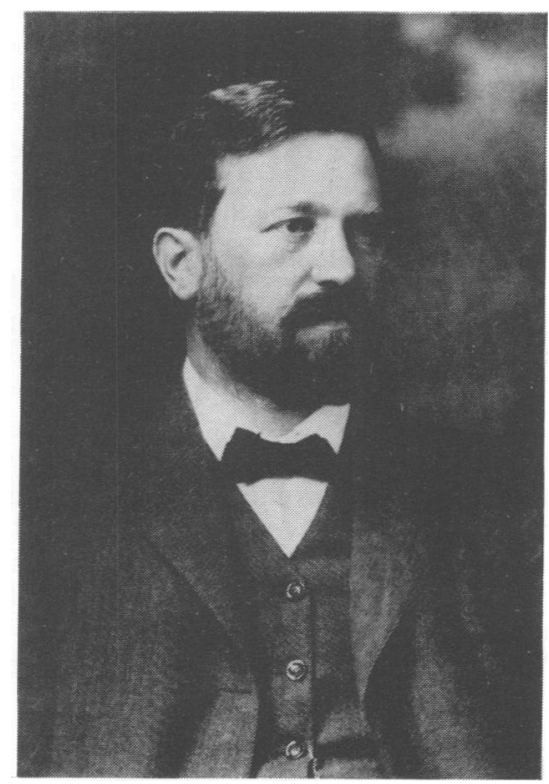

FIG 2 Portrait of Theodor Boveri, about 1909. (Courtesy of Dr Ulrich Wolf, Freiburg. ${ }^{26}$ ) 
fever, certainly were compatible with that diagnosis. Goldschmidt stated that "disease of the gallbladder forced him to interrupt his teaching for a year. An operation performed (a few days before his death) could not save his life". 2.3

Boveri's students included Fritz Baltzer, his biographer, later associated with the University of Bern, Switzerland, and, one of the first, Hans Spemann (1869-1941), who remained in Boveri's institute for many years after completing his doctorate. ${ }^{27}$ Seven years his junior, Spemann enjoyed a close scientific relationship with Boveri and a personal friendship that continued after he was called to Rostock. Spemann was awarded the Nobel Prize in Physiology and Medicine in 1935 for his discovery of the organiser effect in embryonic development. $^{28}$

\section{Boveri's theory of cancer*}

Boveri came to his theory of cancer from the work by him and others of the previous 20 years indicating that the set of chromosomes is a constant characteristic of each species and that each chromosome has a unique constitution. He was particularly led to his cancer theory by his own observations of the consequences of abnormal mitoses in sea urchin eggs. In his 1902 monograph describing such studies, he "added the suggestion that malignant tumors might be the result of a certain abnormal condition of the chromosomes, which may arise from multipolar mitosis". ${ }^{31}$

Hansemann in 1890 had advanced the hypothesis that irregularities of the mitotic process are responsible for disordered growth, ${ }^{32}$ whereas Winge in $1930^{33}$ introduced the concept of selective cellular proliferation "realizing that selection must as inevitably operate on a genotypically mixed population of proliferating cells as on a genotypically mixed population of reproducing organisms". ${ }^{29}$ Hansemann focused on abnormalities of the mitotic process as leading to abnormal growth; Boveri focused on abnormality of the chromosomes as fundamental. Winge's useful selection concept has been elaborated greatly in recent times with studies of the evolution of chromosomal abnormalities in leukaemia and other tumours at various stages.

The essence of Boveri's theory, stated in his own words (as translated by Marcella), was as follows (the numbers are mine).

(1) "The problem of tumors is a cellular problem" $\dagger$ $\left(\mathrm{p}^{3}\right)$.

${ }^{*}$ Ford and Clarke. ${ }^{29}$ Wolf, ${ }^{26}$ and Sager. ${ }^{30}$ among others, have discussed Boveri's theory of cancer in the light of more recent work.

$\dagger$ There are some, even recently, who have challenged the validity of what they term 'cytologism' in cancer research. ${ }^{34-36}$
(2) “... typically every tumor arises from a single cell” $\ddagger\left(\mathrm{p} 40^{3}\right)$.

(3) "This primordial cell of a tumor . . . contains, as a result of an abnormal process, a definite and wrongly combined chromosome-complex."§

(4) "This is . . . the cause of the tendency to rapid cell proliferation, which is passed on to all the descendants of the primordial cell" (p $\left.40^{3}\right)$.

Boveri ${ }^{3}$ also wrote as follows. "A nuclear pathology, which would include according to this conception the theory of malignant tumors, like a nuclear physiology, has scarcely begun to exist." Somatic cell genetic diseases, of which malignant tumours are examples, represent one large category of genetic disease. In these, mutations occur in somatic cells rather than in germ cells as in the disorders generally viewed as proper genetic disease. 'Nuclear pathology' is a term essentially synonymous with 'the morbid anatomy of the human genome'. ${ }^{39}$

\section{Background of the Boveri theory of cancer}

The chromosomes were discovered by Walther Flemming of Kiel, Germany, in 1877. The details of meiosis were described in the next two decades. A main reason that the significance of Mendel'\& experiments in the 1860 s was not recognised was that the chromosomes were not yet known, let alonê meiosis. There was no element of plausibilit favouring mendelism over other theories of heredity, such as the ancestral blending inheritance supported by Francis Galton.

The significance of reduction, as meiosis ${ }^{11}$ was known until at least 1905 , attracted attention from biologists at the end of the last century. Their thinking was reviewed by E B Wilson in his classic The cell in development and inheritance, first published in $1896 .{ }^{14}$ The following quote from this source (p 182-5) indicates that the chromosomes were already suspected to be central to both inheritance and development (the Weismann theory, or Roux-deVries-Weismann theory).

$\ddagger$ This would be called the clonal theory of cancer now. Sir Macfarlane Burnet was perhaps the first to so term it ". . . somatic mutation theories of cancer have been current for many years ... On this view, cancer represents the development by a clone of cells (or more than one) of the capacity to multiply freely without regard to the normal controls which maintain cell relationships in the body" "37 Early studies of the clonality of neoplasms were published by Charles E Ford ${ }^{29}$ and Philip J Fialkow ${ }^{38}$ and their colleagues. Clone comes from the Greek Klon meaning 'twig' or 'slip' and akin to the Greek Klan meaning 'to break'.

$\$$ In a footnote on p $10,{ }^{3}$ Marcella confessed difficulty in translating the word Chromatinbestand. Chromatin-content and chromatin-garniture were other translations she considered. Ford and Clarke ${ }^{29}$ translated the word as chromosome constitution.

|The term meiosis was introduced by Farmer and Moore in a paper in 1905."1 They spelled the word maiosis. In its etymological origin it is the same word as miosis which as currently used refers to reduction in size of the pupil rather than reduction in number of chromosomes. How fortunate that we spell the term differentially in its cytogenetic and ophthalmological uses! 
THEORETICAL SIGNIFICANCE OF

MATURATION

The process of reduction is very obviously a provision to hold constant the number of chromosomes characteristic of the species; for if it did not occur, the number would be doubled in each succeeding generation through union of the germ-cells. But why should the number be constant?

In its modern form this problem was first attacked by Weismann in 1885 , and again in 1887 , though many earlier hypotheses regarding the meaning of the polar bodies had been put forward. His interpretation was based on a remarkable paper published by Wilhelm Roux in 1883 (Ueber die Bedeutung der Kerntheilungsfiguren), in which are developed certain ideas which afterwards formed the foundation of Weismann's whole theory of inheritance and development. Roux argued that the facts of mitosis are only explicable under the assumption that chromatin is not a uniform and homogeneous substance, but differs qualitatively in different regions of the nucleus; that the collection of the chromatin into a thread and its accurate division into two halves is meaningless unless the chromatin in different regions of the thread represents different qualities which are to be divided and distributed to the daughter-cells according to some definite law. He urged that if the chromatin were qualitatively the same throughout the nucleus, direct division would be as efficacious as indirect, and the complicated apparatus of mitosis would be superfluous. Roux and Weismann, each in his own way, subsequently elaborated this conception to a complete theory of inheritance and development, but at this point we may confine our attention to the views of Weismann. The starting-point of his theory is the hypothesis of De Vries that the chromatin is a congeries or colony of invisible self-propagating vital units of biophores somewhat like Darwin's 'gemmules', each of which has the power of determining the development of a particular quality. Weismann conceives these units as aggregated to form units of a higher order known as 'determinants', which in turn are grouped to form 'ids', the latter being identified with the visible chromomeres or chromatin-granules. The ids finally are associated in linear groups to form the 'idants' or chromosomes. Since the biophores differ qualitatively, it follows that the same must be true of the higher units formed by their aggregation. Hence each chromosome has a distinct and definite character of its own, representing a particular group of hereditary qualities. From this it follows that the number of specifically distinct chromosomes is doubled by the union of two germ-cells, a process which if unchecked would quickly lead to an infinite complexity of the chromatin or germ-plasm. The end of maturation, or reduction, is therefore to prevent "the excessive accumulation of different kinds of hereditary tendencies or germ-plasms" through the progressive summation of ancestral chromatins.

We now come to the vital point of Weismann's hypothesis of reduction, about which all later researches have revolved. Assuming with Roux that the different qualities of 'ancestral germ-plasms' are arranged in a linear manner in the spireme-thread and in the chromosomes derived from it, he ventured the prediction ('87) that two kinds of mitosis would be found to occur. The first of these is characterized by a longitudinal splitting of the thread, as in ordinary cell-division, "by means of which all the ancestral germ-plasms are equally distributed in each of the daughter-nuclei after having been divided into halves". This form of division, which he called "equal division' (Aequationstheilung), was then a known fact. The second form, at that time a purely theoretical postulate, he assumed to be of such a character that each daughter-nucleus should receive only half the number of ancestral germ-plasms possessed by the mother-nucleus. This he termed a 'reducing division' (Reduktionstheilung), and suggested that this might be effected either by a transverse division of the chromosomes, or by the divergence and separation of entire chromosomes without division. By either method the number of 'ids' would be reduced; and Weismann argued that such reducing divisions must be involved in the formation of the polar bodies, and in the parallel phenomena of spermatogenesis.

The fulfilment of Weismann's prediction is one of the most interesting results of recent cytological research. It has been demonstrated, in a manner which I believe is incontrovertible, that the reducing divisions postulated by Weismann actually occur, though not precisely in the manner conceived by him.

From this discussion written by Wilson in 1896, it is easily seen that the physical interpretation of mendelism was not possible until after the discovery of the chromosomes and that biological thinking was well prepared for accepting mendelism when it was rediscovered in 1900. Again, Boveri figured in the chromosome theory of mendelism, which, however, is primarily attributed to Sutton. ${ }^{41}$

As a student of McClung at Kansas University, Walter Stanborough Sutton (1877-1916) studied meiosis in the Kansas grasshopper Brachystola magna in the late 1890s for the purpose of resolving the contradictions referred to by Wilson. ${ }^{41}{ }^{42}$ In the autumn of 1901, Sutton went to Columbia University as a graduate student of Wilson's and was in New York when William Bateson (1861-1926), the English advocate of mendelism, lectured there in September 1902. His background in studies of meiosis prepared Sutton for recognising the parallelism between the behaviour of the chromosomes in meiosis and of Mendel's factors in segregation and assortment. In a classic paper, he presented evidence that the hereditary determinants* are on the chromosomes. ${ }^{2}$

Boveri's work provided a basis for the chromosomal theory of mendelism as well as for the chromosome theory of cancer. One necessary condi-

*The term gene was introduced by Johansson of Copenhagen in 1909 'Genetics' was first used in a publication by Bateson in 1906. 
tion for the chromosomal theory of inheritance was the continuity of each chromosome through interphase ('resting phase' or interkinesis) into the next cell division. In beautiful preparations in Ascaris, he showed that the chromosomes continue their existence in specific regions of the diffuse nuclear chromatin mass of interkinesis because they reappear after cell division in the same positions in the two daughter cells.

Another necessity for the chromosomal theory of mendelism was unique genetic content of each chromosome - the individuality of chromosomes. Until about 1902, a prevalent view was that each chromosome was a carrier of the totality of the hereditary material. The genetic difference of separate chromosomes was demonstrated by Boveri using his other favourite material, the sea urchin egg. As early as 1888 , Boveri had found fertilised eggs of Ascaris that formed not the normal two but four mitotic poles. This so-called tetraster egg leads, Boveri demonstrated (see fig $3^{18}$ ), to missegregation of the chromosomes. If chromosomes are genetically non-equivalent, then defective embryos would be expected to develop. The sea urchin eggs provided the material for testing this. These eggs can be artificially fertilised and if one uses much sperm, double fertilisation occurs with resultant tetrapolar or tripolar mitoses. Tetraster eggs cleaved to form four cells rather than the normal two.
Boveri could show that the tetraster or triaster embryo develops with abnormalities. (Marcella was, according to Baltzer, his "most important collaborator, particularly in the dispermic experiments".)

The linear arrangement of genes on chromosomes was established by the works of Thomas Hunt Morgan, like Wilson in the Department of Zoology at Columbia University, and his students. They mapped the relative position of genes on the chromosomes of Drosophila by the linkage principle, starting in 1911. In the same year, E B Wilson 'mapped' (assigned) the first human gene to a specific chromosome. ${ }^{43}$ For this first gene assignment in any mammal, Wilson recognised that the characteristic pedigree pattern of colour blindness (described by Horner, a Swiss ophthalmologist, in the 1870s) was explicable if the human has an XX/Xsex chromosome constitution, if the gene for colour blindness is recessive, and if it is situated on the $\mathrm{X}$ chromosome. (We now know that there are at least two colour blindness genes on the $\mathrm{X}$ chromosome, one for deutan and one for protan colour blindness, and that both are situated near the end of the long arm of the $\mathrm{X}$ chromosome. A third disorder of colour vision, blue-mono-cone-monochromatic colour blindness, is also X linked ( 30370 in McKusick's Mendelian inheritance in $\left.\mathrm{man}^{44}\right)$. The genetic rela- 8 tion of this mutation to those responsible for the other forms is unknown.)

\section{Zur Frage der Entstehung maligner Tumoren}

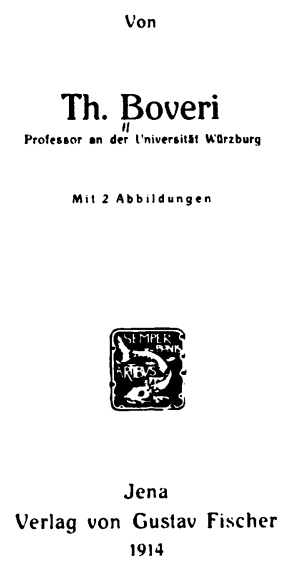

\section{THE ORIGIN \\ OF} MALIGNANT TUMORS

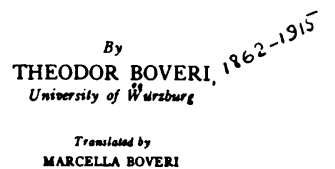

WARCELLA BOVER

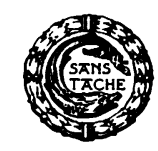

BALTIMORE
THE WILLIAMS \& WILKINS COMPANY 1929

FIG 3 Boveri's monograph expounding the chromosome theory of neoplasia. Left: title page of German edition; right: title page of English translation. 


\section{The impact of Boveri's chromosome theory of cancer}

Having reviewed the background of Boveri's theory, let us examine the after-effect of his 1914 publication. Its early impact seems to have been minimal. In his long obituary of Boveri in 1916, Goldschmidt $^{23}$ made no reference to it. Wilson scarcely mentioned the theory and seemingly did not reference the monograph in the 1925 edition of The Cell. The fact that Marcella translated the book suggests that she sensed a lack of general appreciation for the theory. It is not clear, however, that it achieved any greater recognition after the 1929 publication in translation. Was it before its time, like Mendel's work? Human cytogenetics was in a primitive state, as seen in the uncertainty as to the correct chromosome number and the sex chromosome constitution.

The emphasis, in many ways not inappropriate, on chemicals, viruses, and ionising radiation in carcinogenesis, even with an implied ultimate basis in chromosomal change, may have deflected attention from the fundamental genetic aspects of cancer biology.

Under the heading, "Rediscovering Boveri", Ruth Sager ${ }^{30}$ wrote as follows in 1983: "Boveri's contribution to clear thinking about cancer ranks nearly with Mendel's contribution to clear thinking about genes".

\section{Recapitulation}

This is the story of the first woman to graduate in biology from MIT, who had the good fortune of falling early under the influence of two leading biologists of the day, Sedgwick and Wilson, spawned in the new scientific atmosphere of Johns Hopkins University; who founded the department of biology at one American college, Albertus Magnus, and greatly strengthened the department of biology at another, Vassar; who was the wife and co-worker of the leading cytologist of his day; and who opened her husband's major theoretical work to a larger audience with an English translation.

I am endebted to Sister Thomas Aquin Kelly, OP, Assistant Librarian and Archivist, Albertus Magnus College, for photographs and for a copy of Mrs Boveri's curriculum vitae written in her own hand; to Professor Elof Axel Carlson, Stony Brook, for helpful comments; and to Elizabeth Craig of the MIT Archives and Lisa Browar of Vassar College Library.

\footnotetext{
References

${ }^{1}$ Boveri T. Zür Frage der Entstehung maligner Tumoren. Jena: Verlag von Gustav Fischer, 1914.
}

2 Sutton WS. The chromosomes in heredity. Biol Bull 1903:4: 231-51.

${ }^{3}$ Boveri T. The origin of malignant tumors. (Translated by M Boveri.) Baltimore: Williams and Wilkins. 1929.

${ }^{4}$ Massachusetts Institute of Technology. The Tech 1897:17(5). 5 Jordan EO. Whipple GC. Winslow CEA. A pioneer of public health, William Thompson Sedgwick. New Haven: Yale University Press, 1924.

${ }^{6}$ Morgan TH. Biographical memoir of Edmund Becher Wilson. 1856-1939. Biographical Memoirs Natl Acad Sci USA 1940:21: 315-42.

7 Swanson CP. A history of biology at the Johns Hopkins University. Bios 1951;22:222-62.

${ }^{8}$ French JC. A history of the university founded by Johns Hopkins. Baltimore: Johns Hopkins Press, 1946.

${ }^{9}$ Albertus Magnus College. Notes from the Archive Collection. New Haven, Connecticut.

10 Beirne RR. Let's pick the daisies: the history of the Bryn Mawr School 1885-1967. Baltimore: Bryn Mawr School, 1970.

11 Allen GE. Thomas Hunt Morgan. In: Dictionary of scientific biography. Vol 9. New York: Charles Scribner's Sons. 1974:515-26

12 Fleming D. Jacques Loeb. In: Dictionary of scientific biography. Vol 8. New York: Charles Scribner's Sons, 1973:445-7.

${ }^{13}$ Carter E. Marcella I O'Grady, Mrs Theodor Boveri. Vassar College Archives, Poughkeepsie. New York.

${ }^{14}$ Wilson EB. The cell in development and inheritance. New York: Macmillan, 1896.

15 Goldschmidt R. Portraits from memory: recollections of a zoologist. Berkeley: University of California Press, 1956:111.

${ }_{16}$ The Tech. MIT alumni magazine, 1897, vol XVII, No 5.

17 Boveri M. Personal reminiscences of W C Röntgen. In: Glasser O, ed. Wilhelm Conrad Röntgen and the early history of the Roentgen rays. Springfield, Illinois: Charles C Thomas, 1934:118-98.

${ }^{18}$ Baltzer F. Theodor Boveri. (Translated by C Stern and E Stern.) Science 1964:144:809-15.

${ }^{19}$ Glasser O. Dr W C Röntgen. Springfield. Illinois: Charles C Thomas, 1945.

20 Röntgen WC, ed. Erinnerungen an Theodor Boveri. Tubingen: JCB Mohr, 1918.

${ }^{21}$ Glasser O. Wilhelm Conrad Röntgen and the early history of the Roentgen rays. Springfield, Illinois: Charles C Thomas, 1934.

22 Eakin RM. Great scientists speak again. Berkeley: University of California Press, 1975.

${ }^{23}$ Goldschmidt R. Theodor Boveri. Science 1916:43:263-70.

24 Baltzer F. Theodor Boveri. Life and work of a great biologist 1862-1915. (Translated by D Rudnick.) Berkeley: University of California Press, 1967.

${ }^{25}$ Oppenheimer J. Boveri, Theodor. In: Gillispic CC, ed. Dictionary of scientific biography. Vol 2. New York: Charles Scribner's Sons, 1970:361-5.

${ }^{26}$ Wolf $\mathrm{U}$. Theodor Boveri and his book "On the problem of the origin of malignant tumors". In: German J, ed. Chromosomes and cancer. New York: John Wiley, 1974:3-20.

${ }^{27}$ Mangold O. Hans Spemann. Stuttgart: Wissenschaftliche Verlagsgesellschaft, 1953.

${ }^{28}$ Spemann H. Embryonic development and induction. New Haven: Yale University Press, 1938.

${ }^{29}$ Ford CE. Clarke CM. Cytogenetic evidence of clonal proliferation in primary reticular neoplasms. Can Cancer Conf 1963;5: $129-46$.

${ }^{30}$ Sager R. Genomic rearrangements and the origin of cancer. Rediscovering Boveri: the problem of causality. In: German J, ed. Chromosome mutation and neoplasia. New York: Alan R Liss, 1983:333-46.

${ }^{31}$ Boveri T. Über mehrpolige Mitosen als Mittel zur Analyse des Zellkerns. Verh Phys-med Ges Würzburg 1902;35:67-90. 
${ }^{32}$ Hansemann D. Über asymmetrische Zellteilung in Epithelkerbsen und der biologische Bedeutung. Virch Arch [Pathol Anat] 1890;119:299-326.

${ }^{33}$ Winge $\mathrm{O}$. Zytologische Untersuchungen über die Natur maligner Tumoren. II. Teerkarzinome bei Mauzen. Z Zellforsch 1930;10:683-735.

${ }^{34}$ Smithers DW. Cancer: an attack on cytologism. Lancet 1962;i: 493-9.

${ }^{35}$ Rubin $\mathrm{H}$. Is somatic mutation the major mechanism of malignant transformation? J Natl Cancer Inst 1980;64:995-1000.

${ }^{36}$ Rubin $\mathrm{H}$. Some remarks of cancer as a state of disorganization at the cellular and supracellular levels. In: Le Cam L, Neyman J, eds. Probability models and cancer. New York: North-Holland, 1982.

${ }^{37}$ Burnet M. The clonal selection theory of acquired immunity. Nashville: Vanderbilt University Press, 1959.

${ }^{38}$ Fialkow PJ, Gartler SM, Yoshida A. Clonal origin of chronic myelocytic leukemia in man. Proc Natl Acad Sci USA 1967;58: 1468-71.
${ }^{39}$ McKusick VA. The morbid anatomy of the human genome. Clin Genet 1985;27:238-9.

40 Farmer JB, Moore JES. New investigations in the reduction phenomena of animals and plants. Philos Trans $R$ Soc Lond [Biol] 1905;72:336-53.

41 McKusick VA. Walter S Sutton and the physical basis of Mendelism. Bull Hist Med 1960;34:487-97.

42 McKusick VA. Sutton, Walter Stanborough. In: Gillispie CC, ed. Dictionary of scientific biography. Vol 13. New York: Charles Scribner's Sons, 1976:156-8.

43 Wilson EB. The sex chromosomes. Arch Mikrosk Anat Entwicklungsmech 1911;72:249-71.

44 McKusick VA. Mendelian inheritance in man. 6th ed. Baltimore: Johns Hopkins University Press, 1984.

Correspondence and requests for reprints to Professor V A McKusick, Department of Medicine, The Johns Hopkins Hospital, Baltimore, Maryland 21205, USA. 